\title{
Effects of point-source nutrient addition and mussel removal on epibiotic assemblages in Perumytilus purpuratus beds
}

\author{
Nelson Valdivia ${ }^{\mathrm{a}, 1}$, Martin Thiel ${ }^{\mathrm{a}, \mathrm{b}, *}$ \\ ${ }^{a}$ Facultad de Ciencias de Mar, Universidad Católica del Norte, Larrondo 1281, Coquimbo, Chile \\ ${ }^{\mathrm{b}}$ Centro de Estudios Avanzados en Zonas Áridas (CEAZA), Coquimbo, Chile
}

Received 24 September 2005; accepted 12 June 2006

Available online 6 July 2006

\begin{abstract}
The objective of this study was to evaluate the effects of point-source nutrient addition and mussel removal on species diversity of the epibenthic assemblage of the purple mussel Perumytilus purpuratus. It was hypothesised that mussels cushion the effects of disturbance on the associated organisms and thereby favour species diversity in patches with added nutrients. In order to test this hypothesis, a two-factorial field experiment was conducted at an exposed rocky shore of northern-central Chile in which nutrient addition and mussel removal were manipulated with two levels. Experimental units consisted of $100-\mathrm{cm}^{2}$ mussel plots that were sampled after two months of experimental manipulations. Local nutrient addition was done with coated slow-release fertilisers. Mussel removal treatments consisted in three destructive events applied throughout the experimental phase, and each event consisted in the removal of $20 \%$ of the mussel biomass from each plot. While point-source nutrient addition had only minor effects on diversity, mussel removal had significant and negative effects on faunal species richness and the abundance of suspensionfeeders and sessile organisms. The abundance of predators/scavengers significantly decreased with mussel removal in the presence of nutrient addition. Grazers and mobile organisms were very abundant in the mussel assemblage but their abundance remained unaffected by treatments. Finally, species richness and total abundance of algae were also not affected by the treatments. Although the duration of our experiment was relatively short, we suggest that the effects of local nutrient addition are of minor importance at the study site in comparison to the effects of mussel removal. Based on our results and previous studies conducted in soft-bottom systems, we suggest that physical and biological stress acting on exposed hard-bottom communities overshadows the potential effects of local nutrient addition.
\end{abstract}

(C) 2006 Elsevier B.V. All rights reserved.

Keywords: Nutrients; Disturbance; Rocky shores; Mussel beds; Top-down; Species diversity; Chile

\footnotetext{
* Corresponding author. Tel.: +56 51209939.

E-mail address: thiel@ucn.cl (M. Thiel).

${ }^{1}$ Present address: Biological Station Helgoland, Alfred-WegenerInstitute for Polar and Marine Research, Kurpromenade 201, 27498 Helgoland, Germany.
}

\section{Introduction}

Biogenic habitats are often generated by dominant competitors, i.e. species that monopolise the primary substratum and establish a secondary substratum for smaller organisms (Bruno et al., 2003). Species diversity in these habitats is often comparatively high because they provide refuges from predation (Dieterich et al., 2004), habitable space (Hacker and Steneck, 1990), 
food (Thiel and Ullrich, 2002), shelter from physical stress (Beck, 1998), and mitigation of competitive interactions (Dean and Connell, 1987). These effects may be particularly pronounced in harsh environments, where the presence of biogenic substrata is known to have a strong influence on species diversity (Hacker and Gaines, 1997). However, it is not well known how the positive effects of biogenic habitats are related to other well known forces (disturbance, predation, competition, primary production) in benthic communities.

Nutrient supply and disturbance have been proposed as important factors affecting diversity in ecological communities (Grime, 1977; Connell, 1978; Huston, 1979; Kondoh, 2001). Experimental studies-conducted in soft-bottom mesocosms (Widdicombe and Austen, 2001) and on sheltered rocky shores (Worm et al., 2002; Jara et al., 2006)-suggest that the effect of nutrient addition depends on disturbance and vice versa, indicating strong interaction between these two factors.

Studies testing the effect of nutrient addition on diversity in the marine environment have mainly focused on the response of phytoplankton, fast-growing ephemeral macroalgae, and soft-bottom communities (reviewed by Holmer et al., 2003). These studies have demonstrated that organic enrichment leads to an increase in growth rates of phytoplankton and ephemeral algae, resulting in subsequent changes in the community structure (Holmer et al., 2003). Conversely, hard-bottom communities seem to be more resistant to nutrient addition than those inhabiting sedimentary substrata (Bokn et al., 2003). Although experimental studies have reported a growth response of ephemeral algae to nutrient addition (e.g. Worm et al., 2002), several other studies have found only a weak, or no, effect of this factor on hard-bottom communities (Bokn et al., 2002, 2003; Kraufvelin et al., 2002). Rocky shore systems are usually exposed to strong hydrodynamic forces, which have an important effect on community structure (Sousa, 1979; Paine and Levin, 1981). Water movement can restrict recruitment and survival of ephemeral algae due to their susceptibility to mechanical damage caused by abrasion of waves (Sousa, 1979). Furthermore, since hard-bottom communities harbour a diverse assemblage of mobile and herbivore organisms (Lubchenco, 1978), an eventual increase in algae growth may attract mobile grazers, which can rapidly consume the surplus of primary productivity, and consequently the effects of nutrient addition on the community could be obscured (Worm and Sommer, 2000). These considerations illustrate that effects of nutrient addition on the structure of hard-bottom communities are not as predictable as they are in many other marine environments.

Mussel beds are biogenic habitats that generate spatial complexity and usually have a dense multilayered structure (Alvarado and Castilla, 1996). These complex habitats harbour an abundance of faunal organisms, including nemerteans, polychaetes, molluscs, peracarids, and decapod crustaceans (Lohse, 1993; Tokeshi and Romero, 1995; Gutiérrez et al., 2003). Local nutrient fluxes may be strongly enhanced within mussel beds (Asmus and Asmus, 1991). Because water exchange and wave exposure are important factors affecting the capacity of a water body to dissipate nutrient loads (Pihl et al., 1999), reduced water movement within the mussel matrix could also favour the retention of autochthonous nutrients (Tsuchiya and Nishihira, 1985) and thus increase supply to primary producers associated with mussel beds. While mussels are able to buffer physical stress to some extent, on the outer coast mussel beds are also exposed to strong wave disturbances (disturbance encompasses removal of biomass sensu Grime, 1977) that induce mortality of both mussels themselves and of associated organisms (Paine and Levin, 1981). Lift forces imposed on mussel beds by breaking waves are strong enough to dislodge mussels and initiate a gap formation process (Denny, 1987), being an important source of physical disturbance in mussel beds. These changes in mussel abundance could result in a significant change of the community structure of inhabiting organisms (Lohse, 1993). For example, the reduction in habitat complexity due to disturbance events could limit available shelters for associated fauna, causing increased mortality among the already established organisms. This could be particularly critical for organisms with low mobility and limited clinging abilities (Dean and Connell, 1987).

The purple mussel Perumytilus purpuratus is a common habitat-forming species in the intertidal fringe of exposed shorelines along the Chilean coast. Since Chilean coasts are characterised by seasonal upwelling of cold, oxygen-poor, and nutrient-rich waters (Morales et al., 1996), coastal ecosystems are exposed to a variable nutrient supply. For example, at a northern upwelling centre $\left(23^{\circ} \mathrm{S}\right)$, nitrogen concentration can vary from 0.2 up to $23 \mu \mathrm{mol} \mathrm{Kg}^{-1}$ (Takesue et al., 2004). Moreover, it has been demonstrated that upwelling intensities and consumer pressure interactively affect the structure of intertidal macroalgae communities (Broitman et al., 2001; Nielsen and Navarrete, 2004). Another feature of the Chilean coast is that, at waveswept sites, intertidal organisms are exposed to strong hydrodynamic forces (Castilla et al., 1998), and 
therefore populations of $P$. purpuratus and their associated communities may be strongly affected by these physical disturbances.

The objective of this study was to evaluate the effects of point-source nutrient addition and mussel removal on the abundance and diversity of the epibiont assemblage of $P$. purpuratus. In addition, we examined the effects of nutrient addition and mussel removal on the trophic structure of the assemblage and the abundance of mobile, semi-sessile, and sessile organisms. Our hypothesis is that undisturbed and nutrient-enriched mussel beds harbour a higher abundance and diversity of associates than disturbed mussel beds under natural nutrient concentrations.

\section{Methods}

\subsection{Study site}

The experiment was carried out in Bahía Totoralillo Centro $\left(30^{\circ} 03^{\prime} \mathrm{S} ; 71^{\circ} 28^{\prime} \mathrm{W}\right)$, a wave-exposed bay on the northern-central coast of Chile. The bay is affected by a nearby upwelling centre thought responsible for the high biological productivity of the region (Acuña et al., 1989). Dense patches of Perumytilus purpuratus are found in the intertidal zone on large rocky outcrops (approx. 2-20 m diameter) surrounded by sand. The total zone with mussels along the beach extends over a length of approximately $500 \mathrm{~m}$. These are mussel bed islands along a coastline north of $32^{\circ} \mathrm{S}$, which is largely devoid of extensive intertidal mussel beds (Broitman et al., 2001; Navarrete et al., 2005).

\subsection{Experimental design and field set-up}

The dynamics of the mussel-associated community were examined in a two-factorial field experiment in which nutrient levels and mussel abundance were manipulated. The experiment was conducted between February and April of 2004. Twenty-four plots (experimental units, EUs) were randomly distributed throughout the mussel zone. Each plot consisted of a $100-\mathrm{cm}^{2}$ $(10 \times 10 \mathrm{~cm})$ area, fully covered with mussels forming a multi-layered structure $(0.8-3.9 \mathrm{~cm}$ range length). Mussel samples of a size between 50 and $200 \mathrm{~cm}^{2}$ were shown to yield representative estimates on the numbers of species and individuals (Thiel and Ullrich, 2002). In addition, previous studies on the effects of disturbance in mussel-dominated communities have utilised $7 \times 7 \mathrm{~cm}$ EUs (Lenz et al., 2004a,b), yielding significant response of the communities to experimental treatments. Moreover, these authors evaluated the effect of EU size on community structure, finding no significant response in species richness or composition (see Lenz et al., 2004a). On 5 February 2004, for each EU, 60-70 mussels were detached from rocks, cleaned of all epibiota with a hard plastic brush, and fastened to the rock using a plastic mesh to allow them to reattach to the substratum. At the beginning of the experiment on 4 March 2004, when the mussels had firmly attached to the rock substratum, the mesh was removed and nutrient and disturbance treatments were initiated. Treatments were randomly allocated to plots. To identify plots, mussels at the edges of EUs were scraped off.

\subsection{Point-source nutrient addition treatment}

This factor was manipulated at two levels: (1) no addition (control), and (2) nutrient addition with $220 \mathrm{~g}$ of fertiliser per plot. We used a coated controlled-release fertiliser of 2-4 mm particle size (Plantacote ${ }^{\circledR}$ pluss $6 \mathrm{M}$ of Aglukon, Düsseldorf, Germany), which contained nitrogen $(14 \%)$, phosphate $(9 \%)$, potassium $(15 \%)$, and small amounts of magnesium $(2 \%)$ and micronutrients. The fertiliser for each plot was distributed in two nylon bags $(20 \mathrm{~cm} \times 3 \mathrm{~cm})$ with $1 \mathrm{~mm}$ mesh size. Each bag was placed with its longer side parallel to one side of the EU, and attached to the rock with screws placed at each corner of the mussel plot. To exclude any possible bias from changed hydrodynamics, control plots without fertiliser addition received bags filled with inert stones.

The use of slow-release fertilisers (coated pellets and sticks) is a technique frequently employed in manipulative experiments in benthic systems (reviewed by Worm et al., 2000). In sedimentary environments, nutrient treatments have resulted in 4- to 457-fold increases relative to natural concentrations. In water column enrichment studies, increases in nutrient concentration due to nutrient addition have been 50 to $150 \%$ (Worm et al., 2000). Moreover, these methods have been utilised successfully in manipulating nutrient concentrations in factorial experiments on the effects of disturbance (physical and biological) and nutrient addition on benthic communities (e.g. Hall et al., 2000; Hillebrand et al., 2000; Lotze et al., 2001; Worm et al., 2002) in addition to studies on the microbial activity in seagrass sediments (López and Duarte, 2004).

\subsection{Mussel removal treatment}

Mussel removal was manipulated at two levels: (1) three mussel removals, or (2) no mussel removals throughout the 2-mo experimental phase. Destructive 
Table 1

Species associated with Perumytilus purpuratus at Bahía Totoralillo, north-central coast of Chile

\begin{tabular}{|c|c|c|c|c|}
\hline Taxa & $\begin{array}{l}\text { Total } \\
\text { number }\end{array}$ & $\%$ & $\begin{array}{l}\text { Feed. } \\
\text { group }\end{array}$ & Mobility \\
\hline \multicolumn{5}{|l|}{ Algae } \\
\hline Enteromorpha sp. & $0-100 *$ & 33.3 & - & - \\
\hline Ulva sp. & $0-1^{*}$ & 20.8 & - & - \\
\hline Hildenbrandia lecannellieri & $0-40 *$ & 12.5 & - & - \\
\hline Centroceras clavulatum & $0-1^{*}$ & 4.2 & - & - \\
\hline Ehrytrotrichia sp. & $0-1^{*}$ & 4.2 & - & - \\
\hline Gelidium chilensis & $0-1^{*}$ & 4.2 & - & - \\
\hline Porphyra columbina & $0-100 *$ & 50.0 & - & - \\
\hline Rhodophyta nondet. & $0-1^{*}$ & 29.2 & - & - \\
\hline $\begin{array}{l}\text { Phaeophyceae } \\
\text { encrusting nondet. }\end{array}$ & $0-40 *$ & 25.0 & - & - \\
\hline \multicolumn{5}{|l|}{ Cnidaria } \\
\hline Phymactis papillosa & 58 & 29.2 & $\mathrm{~S}$ & SS \\
\hline \multicolumn{5}{|l|}{ Plathelminthes } \\
\hline Turbellaria nondet. & 49 & 79.2 & $\mathrm{P}$ & M \\
\hline \multicolumn{5}{|l|}{ Nemertea } \\
\hline Amphiporus nelsoni & 24 & 50.0 & $\mathrm{P}$ & M \\
\hline Lineus sp. & 15 & 16.7 & $\mathrm{P}$ & M \\
\hline Nemertopsis bivittata & 24 & 29.2 & $\mathrm{P}$ & M \\
\hline \multicolumn{5}{|l|}{ Annelida } \\
\hline Oligochaeta nondet. & 2 & 8.3 & $\mathrm{D}$ & M \\
\hline Capitella $\mathrm{sp}$ & 2 & 8.3 & $\mathrm{D}$ & SMS \\
\hline Boccardia polybranchia & 19 & 41.7 & $\mathrm{~S}$ & SMS \\
\hline Oriopsis sp. & 7 & 12.5 & $\mathrm{~S}$ & SMS \\
\hline Perinereis falklandica & 27 & 54.2 & $\mathrm{P}$ & M \\
\hline Pseudonereis galapagensis & 27 & 54.2 & $\mathrm{P}$ & M \\
\hline Nereidae juvenile & 49 & 79.2 & $\mathrm{P}$ & M \\
\hline Typosyllis magdalena & 64 & 62.5 & $\mathrm{P}$ & M \\
\hline \multicolumn{5}{|l|}{ Mollusca } \\
\hline Lasaea sp. & 14 & 29.2 & $\mathrm{~S}$ & SS \\
\hline $\begin{array}{l}\text { Perumytilus purpuratus } \\
\qquad(<5 \mathrm{~mm})\end{array}$ & 109 & 83.3 & $\mathrm{~S}$ & SS \\
\hline Semimytilus algosus & 35 & 29.2 & $\mathrm{~S}$ & SS \\
\hline Concholepas concholepas & 1 & 4.2 & $\mathrm{P}$ & M \\
\hline Crepidula sp. & 1 & 4.2 & $\mathrm{~S}$ & SS \\
\hline Gastropoda sp. & 6 & 25.0 & G & $\mathrm{M}$ \\
\hline Nodilittorina araucana & 1 & 4.2 & G & M \\
\hline Nodilittorina peruviana & 6 & 4.2 & $\mathrm{G}$ & M \\
\hline Scurria araucana & 8 & 25.0 & G & M \\
\hline Scurria bohemita & 2 & 8.3 & G & M \\
\hline Scurria ceciliana & 64 & 87.5 & G & M \\
\hline Scurria juvenil & 14 & 37.5 & G & M \\
\hline Scurria sp. & 8 & 29.2 & G & M \\
\hline Scurria zebrina & 5 & 12.5 & G & M \\
\hline Syphonaria lessoni & 20 & 37.5 & G & M \\
\hline Chiton granosus & 14 & 33.3 & G & M \\
\hline \multicolumn{5}{|l|}{ Crustacea } \\
\hline Hyale grandicornis & 221 & 79.2 & G & M \\
\hline Hyale hirtipalma & 103 & 16.7 & G & M \\
\hline Santia dimorpha & 6 & 16.7 & G & M \\
\hline
\end{tabular}

Table 1 (continued)

\begin{tabular}{|c|c|c|c|c|}
\hline Taxa & $\begin{array}{l}\text { Total } \\
\text { number }\end{array}$ & $\%$ & $\begin{array}{l}\text { Feed. } \\
\text { group }\end{array}$ & Mobility \\
\hline Tanais marmoratus & 34 & 62.5 & G & SMS \\
\hline Jehlius cirratus & 115 & 83.3 & $\mathrm{~S}$ & SS \\
\hline Balanus flosculus & 1 & 4.2 & S & SS \\
\hline Acanthocyclus sp. & 76 & 66.7 & $\mathrm{P}$ & M \\
\hline Cyclograpsus cinereus & 4 & 8.3 & $\mathrm{P}$ & M \\
\hline Leptograpsus variegatus c.f. & 1 & 4.2 & $\mathrm{P}$ & M \\
\hline Megalopa Brachyura & 8 & 16.7 & $\mathrm{P}$ & M \\
\hline Megalopa Decapoda & 2 & 4.2 & $\mathrm{P}$ & M \\
\hline Harpacticoidea spp Cyclograpsus & 428 & 79.2 & $\mathrm{G}$ & M \\
\hline \multicolumn{5}{|l|}{ Echinodermata } \\
\hline Echinodermata nondet. & 1 & 4.2 & G & M \\
\hline Echinozoa nondet. & 1 & 4.2 & G & M \\
\hline \multicolumn{5}{|l|}{ Others } \\
\hline Acari nondet. & 1 & 4.2 & $\mathrm{D}$ & M \\
\hline Diptera larval & 3 & 4.2 & $\mathrm{D}$ & $\mathrm{M}$ \\
\hline
\end{tabular}

Total number of individuals registered in the experiment, percentage of samples in which each species was recorded (\%), feeding group, and mobility of each species are given. Legend: $\mathrm{P}=$ predators/scavengers, $\mathrm{S}=$ suspension-feeders, $\mathrm{D}=$ deposit-/detritus-feeders, $\mathrm{G}=$ grazers, $\mathrm{M}=$ mobile, $\mathrm{SS}=$ sessile, $\mathrm{SMS}=$ semi-sessile.

* The abundance of algal species was registered as percent cover of each mussel within each plot. Algal data expressed in this table correspond to the minimum and maximum percentages in the sample.

events were scheduled every two weeks. During each event, $20 \%$ of the biomass present before the disturbance was eliminated by randomly removing individual mussels from the plot. Our rationale was that the reduction of mussel coverage would increase exposure of the epibiotic assemblage to wave action and desiccation.

\subsection{Sampling}

Plots were sampled at the end of the experiment. In order to avoid the effect of different numbers of mussels between the mussel removal levels, we standardised the sample area by sampling a mussel surface area from each plot corresponding to $50 \mathrm{~cm}^{2}$. The mussels and the associated community were carefully placed in plastic vials, taking particular care to ensure that all mobile fauna was collected. Samples were preserved in $7 \%$ formalin until sorting of the associated biota in the laboratory. Samples were washed over a $250 \mu \mathrm{m}$ sieve. The material retained in the sieve was separated under the dissecting microscope, and all organisms sorted to the lowest possible taxonomic level and counted. We classified faunal organisms according to their feeding habits (predators/scavengers, suspension feeders, deposit/ 
detritus feeders, and grazers) and mobility (sessile, semi-sessile, and mobile). This was done on the basis of morphological characteristics of specimens and the available literature (e.g. Fauchald and Jumars, 1979; Rouse and Pleijel, 2001; Thiel and Kruse, 2001; Brusca and Brusca, 2003). In addition, the percent cover of algae species on each mussel was recorded at intervals of $20 \%$ of mussel surface $(0,20,40,60,80$, and $100 \%$ of algal coverage). Algal patches that were too small to fit into the $20 \%$ category were registered as $1 \%$ (presence). The mean abundance of every algal species within each EU was calculated based on all mussels from the respective EU; these values were used for further analyses.

\subsection{Data analysis}

Separate 2-way ANOVAs were performed to test the effects of nutrient addition, mussel removal, and the interaction between treatments on species richness and the abundance of algae, in addition to species richness, evenness, total abundance, abundance of feeding guilds, and mobility groups of fauna associated with $P$. purpuratus. Total abundance data of algae were arcsin-transformed. Data of predator/scavenger organisms were ranked because transformation did not result in homoscedasticity of variances. Variances of other dependent variables were all homoscedastic. The Least Significant Difference test (LSD) was used as a post-hoc test.
Treatment effects on species composition of fauna were examined with a 2-way crossed ANOSIM. This is a non-parametric procedure that uses the difference between average ranked Bray-Curtis dissimilarity values among replicates between samples and within samples to calculate the $\mathrm{R}$ statistic. If $\mathrm{R}$ was significantly different from zero (alpha $=0.05$ ), subsequent SIMPER routine revealed the contribution of single species to these dissimilarities.

Rarefaction analyses were conducted to evaluate whether associated taxa were representatively sampled. Rarefaction analyses, as well as ANOSIM and SIMPER were performed using the PRIMER 5 software package (Plymouth Marine Laboratory).

\section{Results}

\subsection{General overview and species richness}

Altogether we found 54 taxa, being 45 invertebrate and 9 algal species (Table 1). The most abundant invertebrates were the Harpacticoidea spp. with $17.8 \pm 23.7$ individuals per $50 \mathrm{~cm}^{2}($ mean \pm SD), Hyale grandicornis $\left(9.2 \pm 8.2\right.$ ind $\left.50 \mathrm{~cm}^{-2}\right)$, Jehlius cirratus $\left(4.7 \pm 5.2\right.$ ind $\left.50 \mathrm{~cm}^{-2}\right)$, and small recruits $(<5 \mathrm{~mm})$ of $P$. purpuratus $\left(4.5 \pm 5.4\right.$ ind $\left.50 \mathrm{~cm}^{-2}\right)$. The most abundant algae were Enteromorpha sp. and Porphyra columbina, covering 0 to $25.1 \%$ and 0 to $3.5 \%$ surface area per plot, respectively. Grazers were the most abundant feeding group $\left(39.2 \pm 27.8\right.$ ind $\left.50 \mathrm{~cm}^{-2}\right)$,

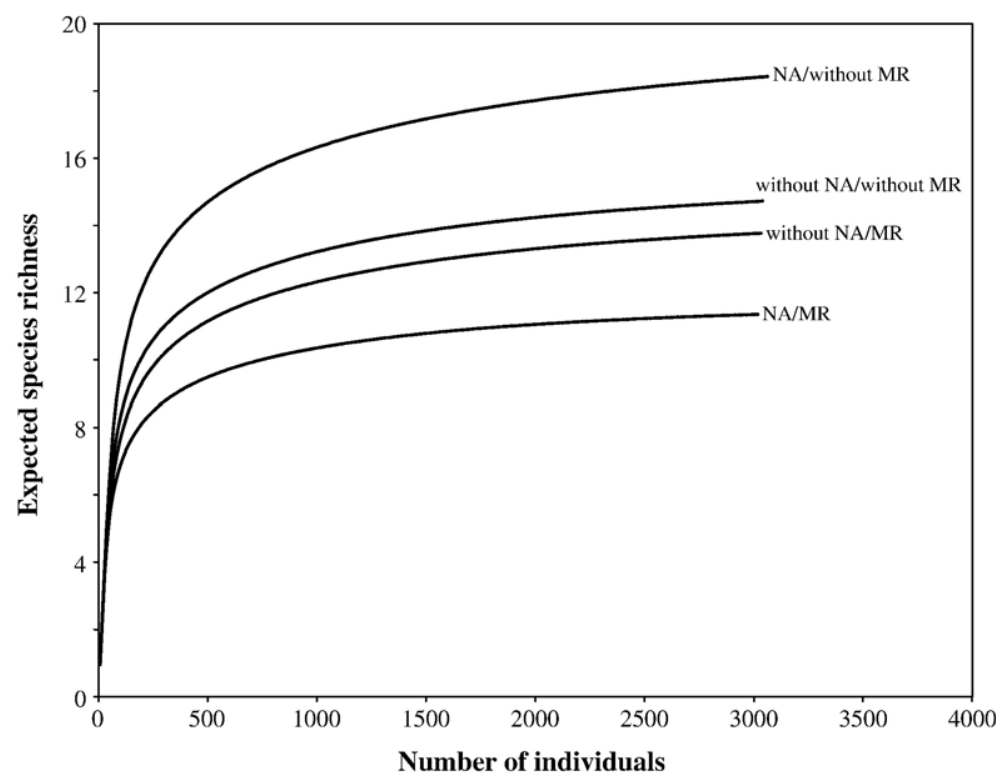

Fig. 1. Rarefaction curves for the four combinations of the nutrient addition and disturbance treatments. Six replicate samples $\left(\right.$ each of $\left.50 \mathrm{~cm}^{2}\right)$ of each treatment combination were taken. $\mathrm{NA}=$ Nutrient addition treatment. $\mathrm{MR}=$ Mussel removal treatment. 
Table 2

Results of the 2-way ANOVAs on species richness, total abundance (ind $50 \mathrm{~cm}^{-2}$ ), and evenness of fauna associated with Perumytilus purpuratus

\begin{tabular}{llrrll}
\hline Variable & Source & df & \multicolumn{1}{l}{ MS } & $F$ & $\mathrm{p}$ \\
\hline Species Richness & Nutrient addition & 1 & 6.00 & 0.39 & 0.536 \\
& Mussel removal & 1 & 104.17 & 6.89 & $\mathbf{0 . 0 1 6}$ \\
& Interaction & 1 & 37.50 & 2.48 & 0.131 \\
Total Abundance & Error & 20 & 15.12 & & \\
& Nutrient addition & 1 & 84.38 & 0.07 & 0.789 \\
& Mussel removal & 1 & 2625.04 & 2.30 & 0.145 \\
& Interaction & 1 & 4401.04 & 3.85 & 0.064 \\
Evenness & Error & 20 & 1142.13 & & \\
& Nutrient addition & 1 & 0.02 & 0.99 & 0.331 \\
& Mussel removal & 1 & 0.00 & 0.26 & 0.609 \\
& Interaction & 1 & 0.00 & 0.09 & 0.764 \\
& Error & 20 & 0.02 & & \\
\hline
\end{tabular}

Significant $\mathrm{p}$-values in bold. Variances were homoscedastic (Cochran's test, $\mathrm{p}>0.05$ ).

followed by suspension-feeders $(21.7 \pm 14.9$ ind $\left.50 \mathrm{~cm}^{-2}\right)$ and predator/scavengers $(7.4 \pm 5.1$ ind $50 \mathrm{~cm}^{-2}$ ), while deposit-/detritus-feeding organisms exhibited the lowest abundance, with $0.3 \pm 0.7$ ind $50 \mathrm{~cm}^{-2}$. With respect to mobility of the associated fauna, mobile organisms were the most abundant (53.5 \pm 31.4 ind $50 \mathrm{~cm}^{-2}$ ), sessile organisms reached $13.6 \pm 9.3$ ind $50 \mathrm{~cm}^{-2}$, and semi-sessiles showed a mean abundance of $2.5 \pm 2.6$ ind $50 \mathrm{~cm}^{-2}$.

Rarefaction curves of the four treatment combinations reached an asymptote (Fig. 1). Consequently, all faunal species were representatively sampled in the treatment combinations and, therefore, an increase of sampling effort (in sample size or number) would not have resulted in a significant increase of species richness. Species richness of fauna was significantly affected by the mussel removal treatment (Table 2). In the absence of mussel removal, species richness tended to be higher than in the presence of mussel removal. In addition, this difference tended to be stronger in the treatments with nutrient addition, but this trend was not significant (Table 2, Fig. 2).

\subsection{Total abundance and evenness}

Mussel removal and nutrient addition did not result in a significant change of total abundance (Table 2, Fig. $3)$. However, the effects of mussel removal were dependent on the level of nutrient addition (Table 2). Total abundance decreased in disturbed plots under enhanced but not under ambient nutrient levels (Fig. 3). Neither nutrient addition nor mussel removal had an effect on the evenness of the associated fauna (Table 2). There also was no interactive effect on the evenness (Table 2).

\subsection{Assemblage composition}

Mussel removal significantly affected the assemblage composition (ANOSIM, global $\mathrm{R}=0.199$, $\mathrm{p}=0.017$ ). Harpacticoidea spp. and $H$. grandicornis accounted for $36.2 \%$ of the variability between disturbance levels (SIMPER-analysis). Harpacticoidea spp. increased from $16.8 \pm 6.6$ in the undisturbed EUs to $18.8 \pm 9.1$ ind $50 \mathrm{~cm}^{-2}$ in the disturbed ones, explaining $23.0 \%$ of the variability. Hyale grandicornis increased in abundance in the mussel removal treatments from $4.7 \pm 6.8$ to $13.7 \pm 7.1$ ind $50 \mathrm{~cm}^{-2}$, accounting for

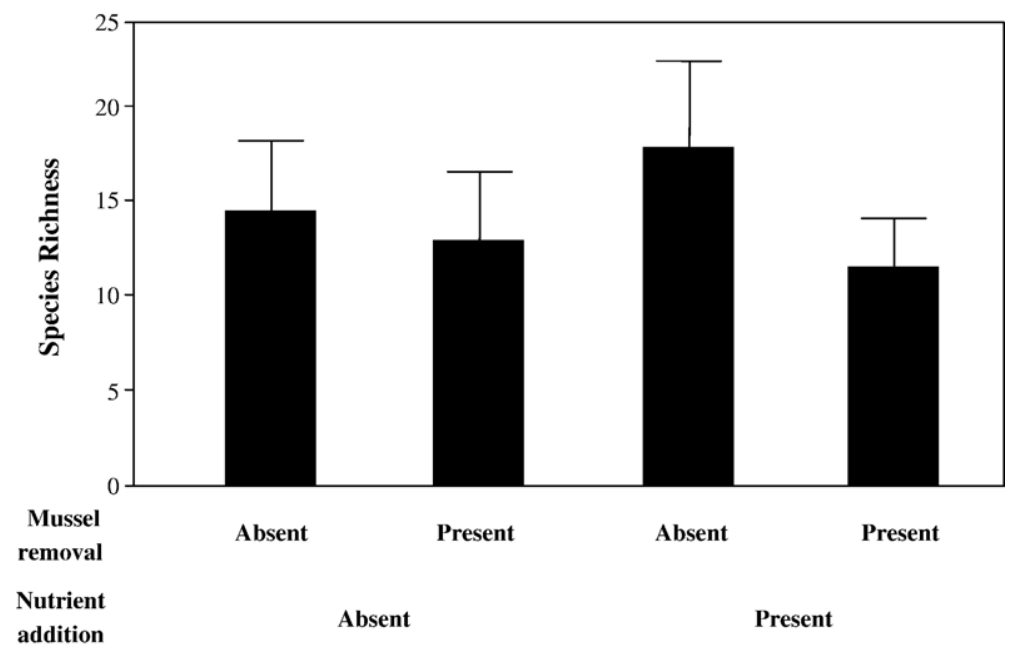

Fig. 2. Effect of nutrient addition and mussel removal treatments on species richness (mean $+\mathrm{SD}, n=6)$ of the fauna associated with Perumytilus purpuratus. Significant differences were found only between the mussel removal levels. 


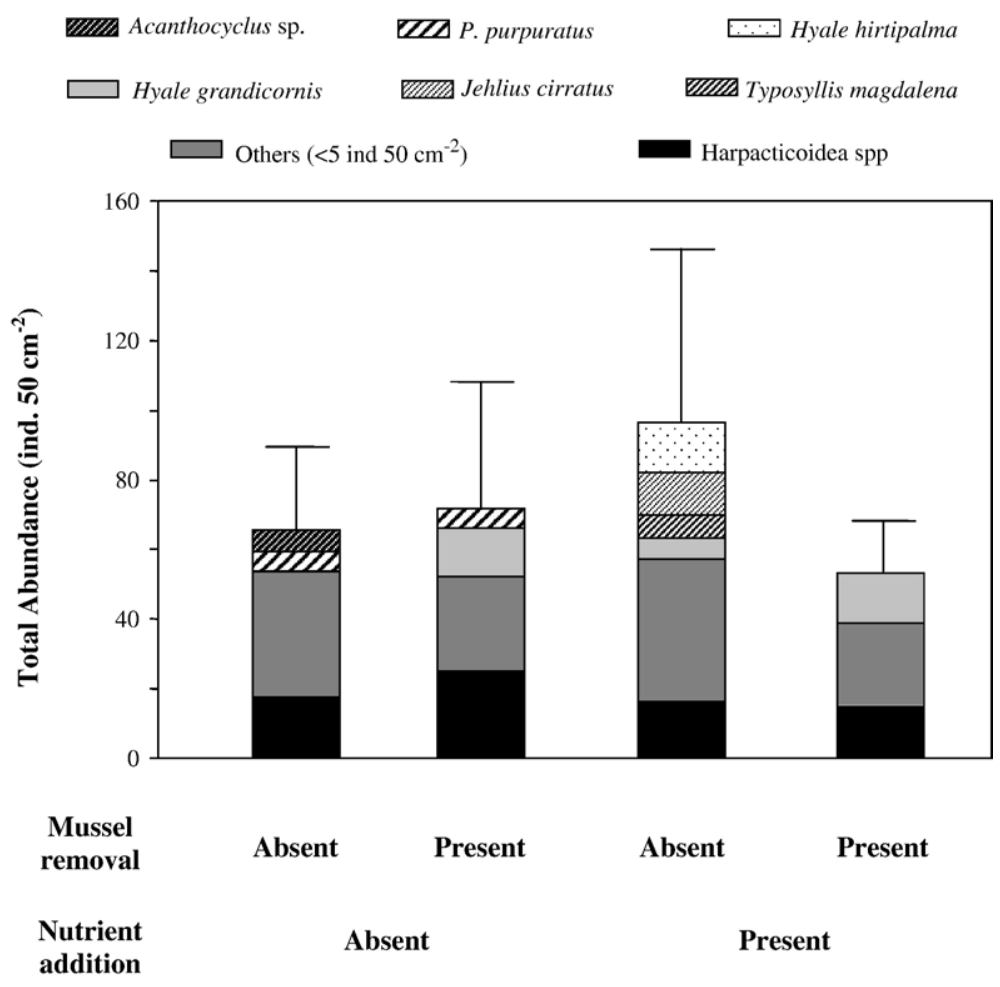

Fig. 3. Effect of nutrient addition and mussel removal treatments on total abundance (ind $50 \mathrm{~cm}^{-2}$, mean $+\mathrm{SD}, n=6$ ) and composition of fauna associated with Perumytilus purpuratus.

$13.2 \%$ of the in-between level dissimilarities. Jehlius cirratus and small recruits of P. purpuratus decreased in mussel removal treatments, explaining $6.4 \%$ and $5.6 \%$ of the dissimilarities. The other species followed a similar trend and explained less than $5.3 \%$ of the dissimilarities between mussel removal levels (SIMPER-analysis). On the other hand, the treatment of nutrient addition had no effect on the species composition (ANOSIM, global $\mathrm{R}=-0.028, \mathrm{p}=0.638$ ). However, we detected an interactive effect of nutrient addition and mussel removal on the abundance of $J$.

Table 3

Results of the 2-way ANOVAs on species richness and abundance of algal species associated with Perumytilus purpuratus

\begin{tabular}{llrrrl}
\hline Variable & Source & df & \multicolumn{1}{c}{ MS } & \multicolumn{1}{l}{$F$} & $\mathrm{p}$ \\
\hline Algae Species & Nutrient addition & 1 & 0.10 & 0.30 & 0.589 \\
Richness & Mussel removal & 1 & 0.40 & 1.15 & 0.294 \\
& Interaction & 1 & 0.01 & 0.01 & 0.945 \\
& Error & 20 & 0.35 & & \\
Algae Total & Nutrient addition & 1 & 1.31 & 0.03 & 0.859 \\
Abundance & Mussel removal & 1 & 67.81 & 1.65 & 0.213 \\
& Interaction & 1 & 3.98 & 0.09 & 0.758 \\
& Error & 20 & 41.03 & & \\
\hline
\end{tabular}

Significant $\mathrm{p}$-values in bold. Variances were homoscedastic (Cochran's test, $\mathrm{p}>0.05$ ). cirratus, which decreased with mussel removal only in the nutrient-added plots (ANOVA, $F_{1,20}=13.23$, $\mathrm{p}=0.002$, Fig. 3). Hyale hirtipalma seemed to exhibit a similar pattern as $J$. cirratus (Fig. 3). This was because one sample of the undisturbed and enriched plots

Table 4

Results of the 2-way ANOVAs on the abundance of feeding groups (ind $50 \mathrm{~cm}^{-2}$ ) of fauna associated with Perumytilus purpuratus

\begin{tabular}{llrrrl}
\hline Variable & Source & df & \multicolumn{1}{l}{ MS } & \multicolumn{1}{l}{$F$} & $\mathrm{p}$ \\
\hline Predators/ & Nutrient addition & 1 & 3.38 & 0.08 & 0.778 \\
Scavengers & Mussel removal & 1 & 60.17 & 1.46 & 0.241 \\
& Interaction & 1 & 247.04 & 6.00 & $\mathbf{0 . 0 2 4}$ \\
& Error & 20 & 41.20 & & \\
Suspension & Nutrient addition & 1 & 104.17 & 0.73 & 0.404 \\
Feeders & Mussel removal & 1 & 1568.17 & 10.94 & $\mathbf{0 . 0 0 4}$ \\
& Interaction & 1 & 541.50 & 3.78 & 0.066 \\
& Error & 20 & 143.33 & & \\
Deposit-/ & Nutrient addition & 1 & 0.17 & 0.37 & 0.550 \\
Detritus- & Mussel removal & 1 & 0.67 & 1.48 & 0.238 \\
Feeders & Interaction & 1 & 1.50 & 3.33 & 0.083 \\
& Error & 20 & 0.45 & & \\
Grazers & Nutrient addition & 1 & 0.67 & 0.00 & 0.978 \\
& Mussel removal & 1 & 6.00 & 0.01 & 0.933 \\
& Interaction & 1 & 1261.50 & 1.53 & 0.231 \\
& Error & 20 & 826.22 & & \\
\hline
\end{tabular}

Significant $\mathrm{p}$-values in bold. Variances were homoscedastic (Cochran's test, $\mathrm{p}>0.05$ ). 
harboured a high abundance of amphipods, resulting in an artificially higher mean abundance, but these differences were not significant (ANOVA, $F_{1,20}=0.62$, $\mathrm{p}=0.4395$, Fig. 3).

\subsection{Trophic structure and functional groups in mussel beds}

Nutrient addition and mussel removal affected neither species richness nor total abundance of algae (Table 3). An interactive effect of these factors on the dependent variables was not detected (Table 3). Nutrient addition and mussel removal had an interactive effect on the abundance of predator/scavenger organisms (Table 4). The abundance of predators/scavengers significantly decreased on nutrient-added plots with the mussel removal treatment (Fig. 4). The abundance of suspension-feeders followed a similar pattern, but it was not statistically significant (Table 4). Suspension-feeders were negatively affected by mussel removal (Table 4, Fig. 4). On the other hand, nutrient and mussel removal treatments did not affect the abundances of deposit/
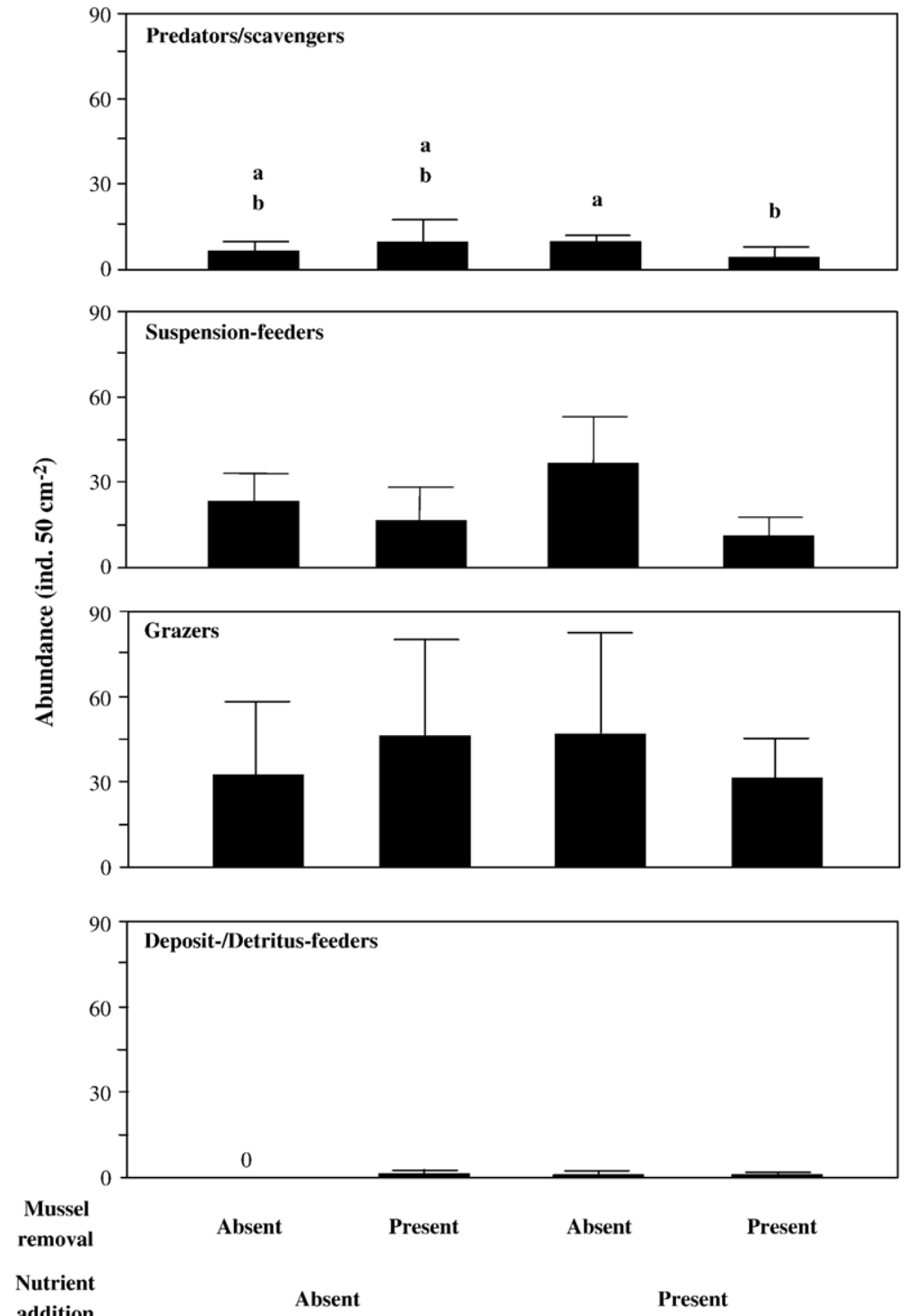

Fig. 4. Effect of nutrient addition and mussel removal treatments on the abundance of feeding guilds (ind. $50 \mathrm{~cm}^{-2}$, mean $+\mathrm{SD}, n=6$ ) of fauna associated with Perumytilus purpuratus. Treatment groups with different letter are statistically different (LSD, $\mathrm{p}<0.05)$. Suspension feeders were affected only by disturbance treatment. The abundance of grazers and deposit/detritus feeders were not affected by treatments. 
Table 5

Results of the 2-way ANOVAs on the abundance of mobility groups (ind $50 \mathrm{~cm}^{-2}$ ) of fauna associated with Perumytilus purpuratus

\begin{tabular}{llrrll}
\hline Variable & Source & df & \multicolumn{1}{l}{ MS } & $F$ & $\mathrm{p}$ \\
\hline Sessile & Nutrient addition & 1 & 3.38 & 0.05 & 0.831 \\
& Mussel removal & 1 & 392.04 & 5.44 & $\mathbf{0 . 0 3 0}$ \\
& Interaction & 1 & 155.04 & 2.15 & 0.158 \\
\multirow{5}{*}{ Semi-sessile } & Error & 20 & 72.11 & & \\
& Nutrient addition & 1 & 0.67 & 0.10 & 0.751 \\
& Mussel removal & 1 & 24.00 & 3.72 & 0.068 \\
& Interaction & 1 & 4.17 & 0.65 & 0.431 \\
Mobile & Error & 20 & 6.45 & & \\
& Nutrient addition & 1 & 51.04 & 0.05 & 0.820 \\
& Mussel removal & 1 & 651.04 & 0.68 & 0.420 \\
& Interaction & 1 & 2795.04 & 2.91 & 0.104 \\
& Error & 20 & 960.94 & & \\
\hline
\end{tabular}

Significant p-values in bold. Variances were homoscedastic (Cochran's test, $\mathrm{p}>0.05$ ).

detritus feeders and grazers (Table 4). The abundance of sessile invertebrates was significantly suppressed by mussel removal (Table 5, Fig. 5), but remained unaffected by nutrient addition and by the interaction of both factors (Table 5). Neither treatments nor interaction significantly affected the abundance of semi-sessile or of mobile organisms (Table 5).

\section{Discussion}

Mussel beds of Perumytilus purpuratus harboured a diverse community of epibionts. While nutrient addition had only minor effects on diversity, mussel removal had significant and negative effects on faunal species richness, and the abundance of sessile and suspensionfeeder organisms. The abundance of predator/scavenger species significantly decreased with mussel removal in the presence of nutrient addition. Finally, species richness and total abundance of algae did not change with either treatment. Our results confirm previous studies on missing nutrient effects in exposed hardbottom communities (e.g. Bokn et al., 2003). This is in contrast to studies conducted in soft-bottom systems, which documented negative effects of organic enrichment on species diversity (Widdicombe and Austen, 2001; Holmer et al., 2003; Elías et al., 2005). Possible reasons for these contrasting community responses between hard-bottom and soft-bottom communities are most likely physical and ecological differences between these systems.

Wave-swept sites of the north-central coasts of Chile are characterised by strong hydrodynamic activities (Castilla et al., 1998). Therefore, factors such as water exchange and wave exposure could have influenced the weak response of the epibiotic assemblage to nutrient addition. First, water exchange may have diluted nutrient concentrations to natural levels, preventing nutrient uptake by the epibiotic primary producers. It has been suggested that water exchange modulates the effect of nutrient addition on the structure of macroalgal communities (Pihl et al., 1999). Second, wave exposure influences the structure of littoral communities (e.g. Lubchenco, 1978) because it restricts growth and survival of ephemeral algae, which are less resistant to physical stress (waves) than larger and massive algae that usually dominate these systems (Littler and Littler, 1980). This may result in a relatively high export of algae dislodged by wave abrasion, which sometimes constitutes an important output of biomass and energy (e.g. Bokn et al., 2003), supporting trophic subsidies to neighbouring systems that include hard- (Rodriguez, 2003) and soft-bottom substrata (Inglis, 1989). Accordingly, wave exposure and the subsequent export of detached algae might be important factors preventing the response of littoral communities to nutrient addition.

In our experiment, grazers and mobile organisms were the most abundant functional groups. Harpacticoid copepods, limpets, and amphipods were common in the present study and therefore their grazing pressure on growing algae could have obscured the effects of nutrient addition by selective grazing on ephemeral algae (Lubchenco, 1978). Nutrient addition is also suggested to attract grazers because food quality increases with addition of nutrients (Worm and Sommer, 2000). Herein, however, we did not observe a positive response of grazers to nutrient addition or disturbance. Probably, the high mobility of these species allows them to quickly move among algal patches (see Buschmann, 1990), and therefore they could be unaffected by treatments. Finally, large-scale removal of grazers is suggested to trigger strong changes in the community structure (Nielsen and Navarrete, 2004), demonstrating the significant top-down control by herbivory in these systems.

Differing from the general absence of effects on the abundance of grazers, the abundance of Hyale grandicornis strongly increased with mussel removal. This species inhabits exposed microhabitats in the intertidal fringe (Lancellotti and Trucco, 1993). While the abundance of this mobile grazer showed a positive response to mussel removal, faunal species richness, abundance of sessile organisms and suspension-feeders decreased in the disturbed plots. Small polychaetes, bivalves, and barnacles mainly composed these groups. Many of these species-with the exception of barnaclesare rapidly dislodged by hydrodynamic forces in 

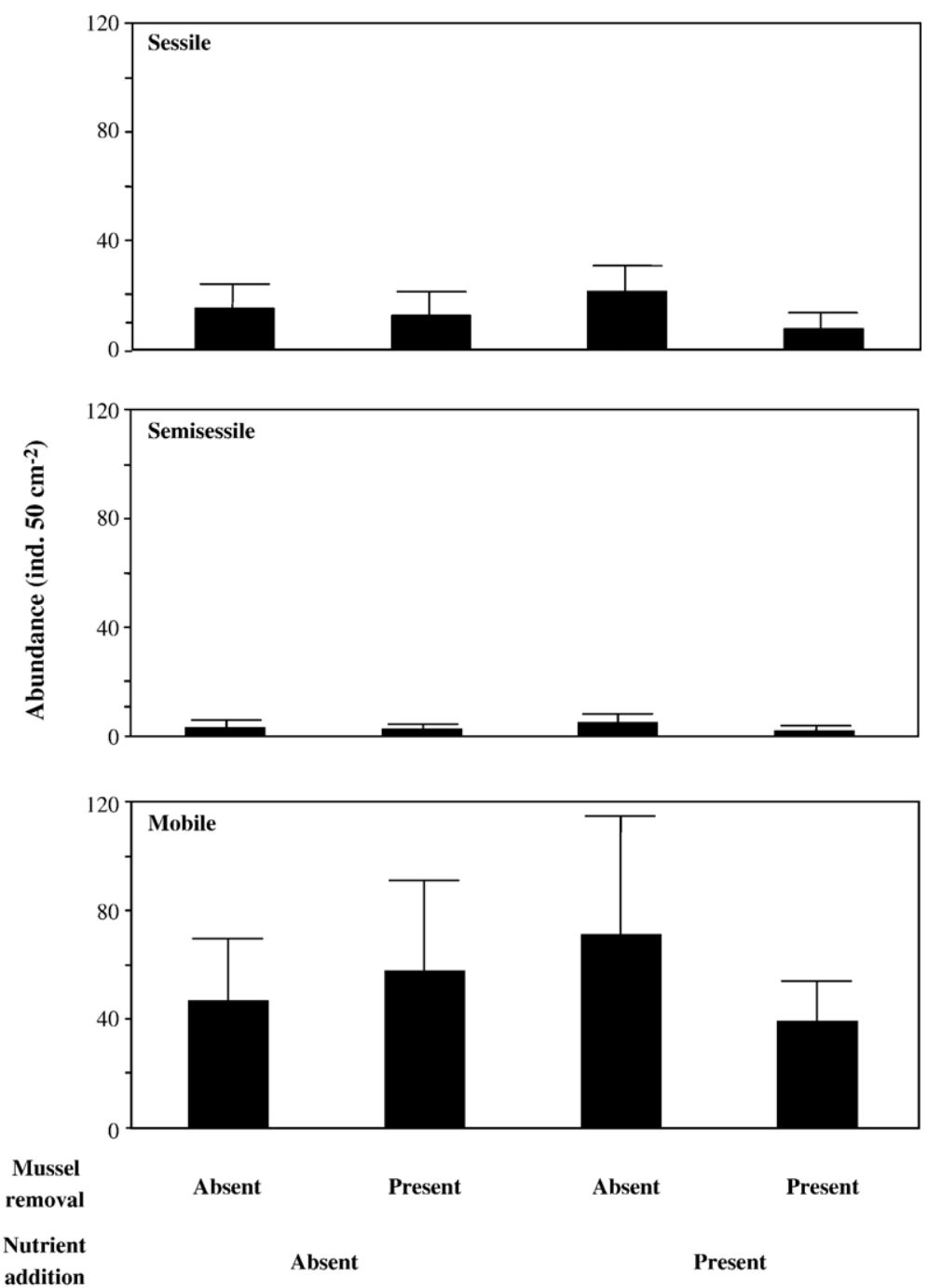

Fig. 5. Effect of nutrient addition and mussel removal treatments on the abundance of sessile, semi-sessile and fully mobile fauna (ind $50 \mathrm{~cm}^{-2}$, mean + SD, $n=6$ ) associated with Perumytilus purpuratus.

exposed habitats. This suggests that species with low mobility and poor abilities to cling to the substratum were negatively affected by mussel removal and therefore a reduction in habitat complexity decreases the niche availability for less tolerant species. Previous studies conducted in complex biogenic substrata have already demonstrated that diversity of inhabiting species is highest at low levels of disturbance (Bruno et al., 2003), and not at intermediate levels as has been demonstrated for sessile macrobenthic communities competing for primary substrata, where disturbance prevents competitive exclusion by suppressing the abundance of the dominant species (e.g. Valdivia et al., 2005). In the present study, we did not identify a dominant species within the epibiotic assemblage that could be reduced by the mussel removal treatment. Diversity of species inhabiting biogenic substrata often increases during succession and does not reach a plateau in mid-successional communities (McKindsey and Bourget, 2001). Competitive exclusion, therefore, should be weak in these environments and competition might be of minor importance in regulating diversity in biogenic substrata.

Herein, a slight but significant interaction between nutrient addition and mussel removal was detected. Nutrient addition tended to increase the abundance of some faunal species in the undisturbed mussel plots. Strong effects of nutrient addition have been documented in other marine environments, such as soft-bottom systems (e.g. Holmer et al., 2003), with widespread 
macroalgal blooms resulting from eutrophication (Valiela et al., 1997). In contrast to hard-bottom systems, soft-bottom habitats are usually located in sheltered areas, where dilution effects due to water movements are limited, possibly leading to a higher retention of nutrients in or near the sediment surface. Since macroalgae are also natural components of shallowwater marine and estuarine soft-bottom communities (Everett, 1994), the relatively reduced water exchange could facilitate high local primary production (Pihl et al., 1999) and a significant change of diversity in response to nutrient addition (Raffaelli, 1999). Export of detached algae from soft-bottom systems is probably also limited in comparison to exposed rocky shores, because in soft-bottom habitats detached algae usually remain in the system as floating algae until they decompose, are deposited on the shore, or sink to the bottom, affecting the underlying community (Salovius et al., 2005). Finally, the role of herbivory also differs between soft- and hard-bottom communities. Although in mussel beds a reduction of grazer densities allows colonisation of ephemeral algae (Albrecht, 1998), strong nutrient addition is often followed by events of severe oxygen depletion in the sediments (Wetzel et al., 2002) causing death or emigration of mobile fauna (Valiela et al., 1997; Reise, 2002). Mussels themselves may enhance these processes by increasing organic enrichment of accumulated sediments (Commito et al., 2005). These features reduce the importance of herbivory with increasing nutrient load in soft-bottom systems. Consequently, it is considered likely that accumulation of ephemeral algae caused by nutrient addition, and the subsequent changes in faunal diversity are higher in soft-bottom systems than on exposed rocky shores. In summary, disturbance appears to exert a control on the faunal diversity in exposed hard-bottom mussel beds by various mechanisms, thereby restricting the potential effects of nutrient addition on these communities.

\section{Acknowledgements}

We are grateful for the constructive comments and suggestions from C. Buschbaum, M. Molis, S. Navarrete and three anonymous reviewers, which significantly improved earlier versions of this manuscript. A. Heidemann, P. Ugalde, M. Weiß, I. Hinojosa, S. Boltaña, $\mathrm{N}$. Vásquez and E. Macaya provided field and laboratory support. N. Rozbaczylo provided indispensable support for the identification of polychaetes. Gratis supply of fertiliser by Aglukon Düsseldorf, Germany is greatly acknowledged. Financial support for this study provided by FONDECYT 1010356 to M.T.

\section{References}

Acuña, E., Moraga, J., Uribe, E., 1989. La zona de Coquimbo: un sistema nerítico de surgencia de alta productividad. Rev. Com. Perm. Pac. Sur. Spec. 145-157.

Albrecht, A., 1998. Soft bottom versus hard rock: community ecology of macroalgae on intertidal mussel beds in the Wadden Sea. J. Exp. Mar. Biol. Ecol. 229, 85-109.

Alvarado, J.L., Castilla, J.C., 1996. Tridimensional matrices of mussels Perumytilus purpuratus on intertidal platforms with varying wave forces in central Chile. Mar. Ecol. Prog. Ser. 133, 135-141.

Asmus, R.M., Asmus, H., 1991. Mussel beds: limiting or promoting phytoplankton? J. Exp. Mar. Biol. Ecol. 148, 215-232.

Beck, M.W., 1998. Comparison of the measurement and effects of habitat structure on gastropods in rocky intertidal and mangrove habitats. Mar. Ecol. Prog. Ser. 169, 165-178.

Bokn, T.L., Moy, F.E., Christie, H., Engelbert, S., Karez, R., Kersting, K., Kraufvelin, P., Lindblad, C., Marba, N., Pedersen, M.F., Sørensen, K., 2002. Are rocky shore ecosystems affected by nutrient-enriched seawater? Some preliminary results from a mesocosm experiment. Hydrobiologia 484, 165-167.

Bokn, T.L., Duarte, C.M., Pedersen, M.F., Marba, N., Moy, F.E., Barrón, C., Bjerkeng, B., Borum, J., Christie, H., Engelbert, S., Fotel, F.L., Hoell, E.E., Karez, R., Kersting, K., Kraufvelin, P., Lindblad, C., Olsen, M., Sanderud, K.A., Sommer, U., Sørensen, K., 2003. The response of experimental rocky shore communities to nutrient additions. Ecosystems 6, 577-594.

Broitman, B.R., Navarrete, S.A., Smith, F., Gains, S.D., 2001. Geographic variation of southeastern Pacific intertidal communities. Mar. Ecol. Prog. Ser. 224, 21-34.

Bruno, J.F., Stachowicz, J.J., Bertness, D., 2003. Inclusion of facilitation into ecological theory. Trends Ecol. Evol. 18, $119-125$.

Brusca, R.C., Brusca, G.J., 2003. Invertebrates. Sinauer Associated, Sunderland. 936 pp.

Buschmann, A.H., 1990. Intertidal macroalgae as refuge and food for Amphipoda in central Chile. Aquat. Bot. 36, 237-245.

Castilla, J.C., Steinmiller, D., Pacheco, C., 1998. Quantifying wave exposure daily and hourly on the intertidal rocky shore of central Chile. Rev. Chil. Hist. Nat. 71, 19-25.

Commito, J.A., Celano, E.A., Celico, H.J., Como, S., Johnson, C.P., 2005. Mussels matter: postlarval dispersal dynamics altered by a spatially complex ecosystem engineer. J. Exp. Mar. Biol. Ecol. 316, 133-147.

Connell, J.H., 1978. Diversity in tropical rain forests and coral reefs. Science 199, 1302-1310.

Dean, T.A., Connell, J.H., 1987. Marine invertebrates in an algal succession. III. Mechanisms linking habitat complexity with diversity. J. Exp. Mar. Biol. Ecol. 109, 249-273.

Denny, M.W., 1987. Lift as a mechanism of patch initiation in mussel beds. J. Exp. Mar. Biol. 231-245.

Dieterich, A., Mörtl, M., Eckman, R., 2004. The effects of zebra mussels (Dreissena polymorpha) on the foraging success of eurasian perch (Perca fluviatilis) and ruffe (Gymnocephalus cernuus). Intern. Rev. Hydrobiol. 89, 229-237.

Elías, R., Palacios, J.R., Rivero, M.S., Vallarino, E.A., 2005. Shortterm responses to sewage discharge and storms of subtidal sandbottom macrozoobenthic assemblages off Mar del Plata City, Argentina (SW Atlantic). J. Sea. Res. 53, 231-242.

Everett, R.A., 1994. Macroalgae in marine soft-sediment communities: effects on benthic faunal assemblages. J. Exp. Mar. Biol. Ecol. 175, 253-274. 
Fauchald, K.P., Jumars, A., 1979. The diet of worms: a study of polychaete feeding guilds. Oceanogr. Mar. Biol. Ann. Rev. 17, 139-284.

Grime, J.P., 1977. Evidence for the existence of three primary strategies in plants and its relevance to ecological and evolutionary theory. Am. Nat. 111, 1169-1194.

Gutiérrez, J., Jones, C., Strayer, D., Iribarne, O., 2003. Mollusks as ecosystem engineers: the role of shell production in aquatic habitats. Oikos 101, 79-90.

Hacker, S., Gaines, S., 1997. Some implications of direct positive interactions for community species diversity. Ecology 78, 1990-2009.

Hacker, S., Steneck, R., 1990. Habitat architecture and the abundance and body-size-dependent habitat of a phytal amphypod. Ecology $71,2269-2285$.

Hall, S.J., Gray, S.A., Hammett, Z.L., 2000. Biodiversity-productivity relations: an experimental evaluation of mechanisms. Oecologia $122,545-555$.

Hillebrand, H., Worm, B., Lotze, H.K., 2000. Marine microbenthic community structure regulated by nitrogen loading and grazing pressure. Mar. Ecol. Prog. Ser. 204, 27-38.

Holmer, M., Pérez, M., Duarte, C.M., 2003. Benthic primary producers-a neglected environmental problem in Mediterranean maricultures? Mar. Poll. Bull. 46, 1372-1376.

Huston, M.A., 1979. A general hypothesis of species diversity. Am. Nat. 113, 81-101.

Inglis, G., 1989. The colonization and degradation of stranded Macrocystis pyrifera (L.) C. Ag. by the macrofauna of a New Zealand sandy beach. J. Exp. Mar. Biol. Ecol. 125, 203-217.

Jara, V., Miyamoto, J.H.S., Da Gama, B.A.P., Molis, M., Wahl, M., Pereira, R.C., 2006. Limited evidence of interactive disturbance and nutrient effects on the diversity of macrobenthic assemblages. Mar. Ecol. Prog. Ser. 308, 37-48.

Kondoh, M., 2001. Unifying the relationships of species richness to productivity and disturbance. Proc. R. Soc. Lond., B 268, 269-271.

Kraufvelin, P., Christie, H., Olsen, M., 2002. Littoral macrofauna (secondary) responses to experimental nutrient addition to rocky shore mesocosms and a coastal lagoon. Hydrobiologia 484, 149-166.

Lancellotti, D.A., Trucco, R.G., 1993. Distribution patterns and coexistence of 6 species of the amphipod genus Hyale. Mar. Ecol. Prog. Ser. 93, 131-141.

Lenz, M., Molis, M., Wahl, M., 2004a. Experimental test of the intermediate disturbance hypothesis: frequency of emersion on fouling communities. J. Exp. Mar. Biol. Ecol. 305, 247-266.

Lenz, M., Molis, M., Wahl, M., 2004b. Testing the intermediate disturbance hypothesis: response of fouling communities to various levels of emersion intensity. Mar. Ecol. Prog. Ser. 278, $53-65$.

Littler, M.M., Littler, D.S., 1980. The evolution of thallus form and survival strategies in benthic marine macroalgae: field and laboratory tests of a functional form model. Am. Nat. 116, $25-44$.

Lohse, D.P., 1993. The importance of secondary substratum in a rocky intertidal community. J. Exp. Mar. Biol. Ecol. 166, 1-17.

López, N.I., Duarte, C.M., 2004. Dimethyl sulfoxide (DMSO) reduction potential in Mediterranean seagrass (Posidonia oceanica) sediments. J. Sea. Res. 51, 11-20.

Lotze, H.K., Worm, B., Sommer, U., 2001. Strong bottom-up and topdown control of early life stages of macroalgae. Limnol. Oceanogr. $46,749-757$.
Lubchenco, J., 1978. Plant species diversity in a marine intertidal community: importance of herbivore food preference and algal competitive abilities. Am. Nat. 112, 23-39.

McKindsey, C.W., Bourget, E., 2001. Diversity of a northern rocky intertidal community: the influence of body size and succession. Ecology 82, 3462-3478.

Morales, C.E., Blanco, J.L., Braun, M., Reyes, H., Silva, N., 1996 Chlorophyll-a distribution and associated oceanographic conditions in the upwelling region off northern Chile during the winter and spring 1993. Deep-Sea Res. Part. I 43, 267-289.

Navarrete, S.A., Wieters, E.A., Broitman, B.R., Castilla, J.C., 2005 Scales of benthic-pelagic coupling and the intensity of species interactions: from recruitment limitation to top-down control. Proc. Nat. Acad. Sci. 102, 18046-18051.

Nielsen, K.J., Navarrete, S.A., 2004. Mesoscale regulation comes from the bottom-up: intertidal interactions between consumers and upwelling. Ecol. Lett. 7, 31-41.

Paine, R., Levin, S.A., 1981. Intertidal landscapes: disturbance and the dynamics of pattern. Ecol. Monogr. 51, 145-178.

Pihl, L., Svenson, A., Moksnes, P.-O., Wennhage, H., 1999. Distribution of green algal mats throughout shallow soft bottoms of the Swedish Skagerrak archipelago in relation to nutrient sources and wave exposure. J. Sea. Res. 41, 281-294.

Raffaelli, D., 1999. Nutrient addition and trophic organization in an estuarine food web. Acta Oecol. 20, 449-461.

Reise, K., 2002. Sediment mediated interactions in coastal waters. J. Sea. Res. 48, 127-141.

Rodriguez, S.R., 2003. Consumption of drift kelp by intertidal populations of sea urchin Tetrapygus niger on the central Chilean coast: possible consequences at different ecological levels. Mar. Ecol. Prog. Ser. 251, 141-151.

Rouse, G.W., Pleijel, F., 2001. Polychaetes. Oxford University Press, Hong Kong. 354 pp.

Salovius, S., Nyqvist, M., Bonsdorff, E., 2005. Life in the fast lane: macrobenthos use temporary drifting algal habitats. J. Sea. Res. 53, $168-180$.

Sousa, W.P., 1979. Disturbance in marine intertidal boulder fields: the nonequilibrium maintenance of species diversity. Ecology 60 , 1225-1239.

Takesue, R.K., Van Geen, A., Carriquiry, J.D., Ortiz, E., GodinezOrta, L., Granados, I., Saldivar, M., Ortlieb, L., Escribano, R., Guzmán, N., Castilla, J.C., Varas, M., Salamanca, M., Figueroa, C., 2004. Influence of coastal upwelling and El Niño-Southern Oscillation on nearshore water along Baja California and Chile: Shore-based monitoring during 1997-2000. J. Geophys. Res. C $109,1-14$.

Thiel, M., Kruse, I., 2001. Status of the Nemertea as predators in marine ecosystems. Hydrobiologia 456, 21-32.

Thiel, M., Ullrich, N., 2002. Hard rock versus soft bottom: the fauna associated with intertidal mussel beds on hard bottoms along the coast of Chile, and considerations on the functional role of mussel beds. Helgol. Meeresunters. 56, 21-30.

Tokeshi, M., Romero, L., 1995. Filling a gap: dynamics of space occupancy on a mussel-dominated subtropical rocky shore. Mar. Ecol. Prog. Ser. 119, 167-176.

Tsuchiya, M., Nishihira, M., 1985. Islands of Mytilus as a habitat of small intertidal animals: effect of island size on community structure. Mar. Ecol. Prog. Ser. 25, 71-81.

Valdivia, N., Heidemann, A., Thiel, M., Molis, M., Wahl, M., 2005. Effects of disturbance on the diversity of hard-bottom macrobenthic communities on the coast of Chile. Mar. Ecol. Prog. Ser. $299,45-54$. 
Valiela, I., McClelland, J., Hauxwell, J., Behr, P.J., Hersh, D., Foreman, K., 1997. Macroalgal blooms in shallow estuarines: controls and ecophysiological and ecosystem consequences. Limnol. Oceanogr. 42, 1105-1118.

Wetzel, M.A., Weber, A., Giere, O., 2002. Re-colonization of anoxic/ sulfidic sediments by marine nematodes after experimental removal of macroalgal cover. Mar. Biol. 141, 679-689.

Widdicombe, S., Austen, M.C., 2001. The interaction between physical disturbance and organic enrichment: an important element in structuring benthic communities. Limnol. Oceanogr. 46, $1720-1733$.
Worm, B., Sommer, U., 2000. Rapid direct and indirect effects of a single nutrient pulse in a seaweed-epiphyte-grazer system. Mar. Ecol. Prog. Ser. 202, 283-288.

Worm, B., Reusch, T.B.H., Lotze, H.K., 2000. In situ nutrient enrichment: methods for marine benthic ecology. Int. Rev. Hydrobiol. 85, 359-375.

Worm, B., Lotze, H.K., Hillebrand, H., Sommer, U., 2002. Consumer versus resource control of species diversity and ecosystem functioning. Nature 417, 848-851. 